\title{
The Association between the Mental Health Nurse-to-Registered Nurse Ratio and Patient Outcomes in Psychiatric Inpatient Wards: A Systematic Review
}

\author{
Nompilo Moyo ${ }^{1, *}{ }^{\mathbb{D}}$, Martin Jones ${ }^{2}$, Diana Kushemererwa ${ }^{1}$, Sandesh Pantha ${ }^{1} \mathbb{D}$, Sue Gilbert ${ }^{1}$, \\ Lorena Romero ${ }^{3}$ and Richard Gray ${ }^{1}(\mathbb{D}$ \\ 1 School of Nursing and Midwifery, La Trobe University, Bundoora, VIC 3086, Australia; \\ d.kushemererwa@latrobe.edu.au (D.K.); s.pantha@latrobe.edu.au (S.P.); s.gilbert@latrobe.edu.au (S.G.); \\ R.Gray@latrobe.edu.au (R.G.) \\ 2 Department of Rural Health, University of South Australia, North Terrace, Adelaide, SA 5000, Australia; \\ Martin.Jones@unisa.edu.au \\ 3 Alfred Hospital, 55 Commercial Road, Melbourne, VIC 300, Australia; 1.romero@alfred.org.au \\ * Correspondence: n.moyo@latrobe.edu.au; Tel.: +61-41-005-8750
}

Received: 28 August 2020; Accepted: 16 September 2020; Published: 21 September 2020

\begin{abstract}
Nursing skill mix in inpatient mental health wards varies considerably between countries. Some countries have an all-registered mental health nurse workforce; others have a mix of registered mental health and registered nurses. Understanding the optimal nursing skill mix in mental health inpatient units would inform service planning. This report aims to examine the association between the registered mental health nurse-to-registered nurse ratio and psychiatric readmission (or referral to community crisis services) in adult mental health inpatients. A systematic review was performed. We searched key databases for observational and experimental studies. Two researchers completed title-and-abstract and full-text screening. Our search identified 7956 citations. A full-text review of four papers was undertaken. No studies met our inclusion criteria. We report an empty review. Despite the obvious importance of the research question for the safe staffing of inpatient mental health services, there are no studies that have tested this association.
\end{abstract}

\section{PROSPERO Registration: CRD42019145156}

Keywords: mental health; nursing; inpatient; skill mix; admission; relapse; empty review

\section{Introduction}

\subsection{Nursing Skill Mix in Medical and Surgical Wards}

To date, there have been at least 21 observational studies that have tested the association between the educational preparation of nurses and patient outcomes [1-21]. Half of these studies have focused on surgical patients only. The remainder have been on medical, intensive care and specialist units. As far as we can determine, the first study to test the association between nursing skill mix and patient outcomes was reported in 1976 [22]. Most of these studies (15/20) are from an overlapping group of authors and have essentially followed the same methodology, i.e., estimating the skill mix, education and nurse-to-patient ratio by surveying nurses $[11,16,21]$ and extracting aggregated patient mortality data from hospital administrative sources. Studies have generally reported a significant association between a more highly educated nursing workforce and a lower risk of mortality $[12,15,16]$. 
There are important methodological limitations that need to be considered when appraising these skill-mix studies, particularly around how skill mix is measured. Five studies $[9,10,16,20,21]$ have reported using the same questionnaire to measure skill mix. While some authors have stated that the questionnaire has been validated, this is difficult to track in the published literature. We have been unable to get hold of a copy of the questionnaire from the original authors because of apparent copyright issues. It is likely that a self-reported measure of skill mix may lack precision, e.g., nurses asked about their qualifications may inflate their achievements.

Evidence from medical and surgical skill-mix studies cannot be generalised to mental health settings because nurses are working with different populations-typically, people with severe mental disorders-and the care required is different: a combination of psychosocial interventions, risk assessment, containment and medication management [23-25]. Psychosocial interventions are important in mental health and have been shown to be effective in reducing symptoms of anxiety, depression and posttraumatic stress disorder [26].

\subsection{Nursing Skill Mix and Patient Outcomes in Mental Health Settings}

One previous systematic review examined the association between mental health-nursing skill mix and relapse [27]. The review, focused on community mental health nurses and included two studies, involving 356 patients. The studies were rated as having a low-moderate risk of bias [27]. The authors reported that there was not enough evidence to conclude that community mental health nursing reduced the risk of admission to psychiatric inpatient facilities.

In the [27] review, admission and not mortality was used as the primary outcome of interest; this is because death is a comparatively rare outcome in mental health settings. Demonstrating an association between skill mix and mortality would require an unfeasibly large sample size. Aside from admission to psychiatric hospital, the other candidate outcomes that could be used in mental health-nursing skill-mix research are untoward incidents that include violence and aggression, absconding, seclusion and physical and mechanical restraint [28-30].

Untoward incidents have previously been used in evaluations of mental health service interventions. For example, Chou et al. [31] conducted an observational study to test if there was an association between patient, environmental and nurse staffing factors and assaults by patients on clinicians and patients in acute-inpatient psychiatric units. The authors included 287 patients and 855 assaults. The study showed an association between clinical experience and violence training and the risk of assault. However, the authors may have overestimated the actual number of assaults because they counted violence toward objects and verbal threats as assaults. This lack of consistency in how untoward incidents are defined and measured is a major limitation in their use as a valid measure in mental health research.

The use of untoward incidents (violence, aggression, restraint and seclusion) as an outcome in research requires careful consideration. Only a minority of people experiencing mental illness who are admitted to hospital will be violent or aggressive. If this is used as a research outcome, any observed association will likely only be in a small subgroup of patients (i.e., those that have been violent). There is also evidence that mental health clinicians working in different environments will have different views about what constitutes an untoward incident [32]. For example, the threshold for reporting violent incidents is considered higher in Psychiatry Intensive Care. Units (PICU), compared with in general acute-inpatient wards [32]. The number of untoward incidents may also change when practice on a ward is being observed as part of a research study or clinical audit. For example, if nurses are aware that there is a study ongoing on their ward where the outcome (a measure of success) is the number of untoward incidents, they may be less likely to report incidents because they want to please the researcher (a sort of social desirability bias). As a consequence, the number of reported incidents may seem to decline when there has, in fact, been no change [30]. 


\subsection{Why Is Admission to Hospital a Good Research Outcome?}

People who experience mental illness are admitted to inpatient care for the emergency treatment of acute psychiatric symptoms (hallucinations, delusions and mania) that are causing the patient distress and may be placing themselves or others at risk [33]. It has been argued that some admissions to psychiatric hospital are planned-e.g., for the initiation of clozapine. However, there is little evidence to demonstrate that this is a common occurrence [34,35]. Mental disorders are long-term conditions [36,37], and most people admitted to a psychiatric ward will have subsequent admissions [38-40]. For example, Schennach et al. [38] examined relapse and its predictors among patients with schizophrenia within one year of hospital discharge. Two hundred patients were included in the study. The authors reported that 104 patients (52\%) had at least one relapse in the first year after hospital discharge, and $34(17 \%)$ had multiple relapses. Among patients who relapsed, 78 (75\%) were admitted as a result of the exacerbation of their symptoms [38].

Data on admissions may be reliable, as they are recorded as a part of routine hospital administrative work [41,42]. Admission data have been used by researchers internationally for many years in both medical and psychiatric settings $[40,43]$. However, there are notable limitations to using readmission as an outcome in mental health research. Patients may relocate or change residential address to a different catchment area and be admitted to a different hospital. While not a perfect measure, admission to a psychiatric hospital is a good proxy for relapse and is meaningful to patients, their family and friends, mental health services and the wider community [44-46].

\subsection{Nursing Skill Mix on Mental Health Wards}

A mental health nurse is a nurse who has completed specialist post-qualification education in mental health nursing, which builds upon primary generalist nursing education [47]. The nursing skill mix in mental health settings varies considerably from country to country. For example, in the UK, psychiatric wards are staffed exclusively by nurses that hold a specialist mental health registration $[48,49]$. Other countries-for example, Australia-have a mix of registered mental health and registered nurses working in a psychiatric inpatient unit $[48,49]$. Some countries have no mental health nurses working on psychiatric wards; nurses are registered but with no specialist education.

There is a need to investigate the association between nursing skill mix and patient outcome in inpatient psychiatric settings.

\subsection{Aims}

This systematic review aims to synthesize evidence examining the association between the mental health-to-registered nurse ratio and patient outcomes (relapse determined by hospital admission) in inpatient mental health settings.

\subsection{Review Question}

Is there an association between the registered mental health-to-registered nurse ratio and relapse in adult mental health inpatients?

\section{Materials and Methods}

We report Part Two of the registered report. Part One was published in the Journal of Psychiatric and Mental Health Nursing [50]. We therefore only present a summary of our methods. No changes were made to our study methodology subsequent to publishing Part One of this registered report. Our reporting adheres to the Preferred Reporting Items for Systematic Reviews and Meta-Analyses 2015 checklist (PRISMA) [51].

\subsection{Search Strategy}

We searched five key databases (MEDLINE, CINAHL, EMBASE, Cochrane Central and PsycINFO). 
We used synonyms and related terms for the three key study concepts: mental health inpatients, nursing skill mix, and psychiatric nursing. Our search strategy shown in Table 1 was externally peer-reviewed. At least two reviewers (N.M., D.K. and S.P.) completed title-and-abstract and full-text screening. A third reviewer (R.G.) resolved any conflicts. Data extraction was also undertaken by two reviewers (N.M. and R.G.).

Table 1. Database(s): Ovid MEDLINE(R), ALL 1946 to 30 July 2019.

\begin{tabular}{|c|c|}
\hline \multicolumn{2}{|c|}{ Search Strategy: } \\
\hline$\#$ & Searches \\
\hline 1 & exp Hospitals, Psychiatric/ \\
\hline 2 & exp Mental Disorders/ \\
\hline 3 & exp Psychiatric Department, Hospital/ \\
\hline 4 & exp Mental Health/ \\
\hline 5 & $\begin{array}{l}\text { (acute mental unit* or psychiatric inpatient care or } \\
\text { psychiatric ward * or mental ward * or mental health } \\
\text { unit *).mp. }\end{array}$ \\
\hline 6 & $\begin{array}{l}\text { (psychiatric service * or mental health care or } \\
\text { psychiatric care or mental health care).mp. }\end{array}$ \\
\hline 7 & $\begin{array}{l}\text { (mental health hospital or psychiatric institution * or } \\
\text { mental health institution * or mental health setting * } \\
\text { or psychiatric setting * or psychiatric hospital }{ }^{*} \text { ).mp. }\end{array}$ \\
\hline 8 & $\begin{array}{l}\text { (mental health inpatient or psych * inpatient }{ }^{*} \text { or } \\
\text { psych * patient }{ }^{*} \text { or mentally ill patient }{ }^{*} \text { or mental } \\
\left.\text { patient or mental health patient }{ }^{*}\right) \cdot \mathrm{mp} .\end{array}$ \\
\hline 9 & 1 or 2 or 3 or 4 or 5 or 6 or 7 or 8 \\
\hline 10 & $\begin{array}{l}\text { (nurse patient ratio * or nursing staffing ratio * or } \\
\text { nursing skill ratio * or nursing skill mix * or hours per } \\
\text { patient day or nurse per patient day or full time } \\
\text { equivalent or nurs * staff* or nurs * schedul * or task } \\
\text { allocation * or delegation).mp. }\end{array}$ \\
\hline 11 & $\begin{array}{l}\text { (nursing staff numbers or staff mix or staffing } \\
\text { levels).mp. }\end{array}$ \\
\hline 12 & $\begin{array}{l}\text { (educational preparation or education level or } \\
\text { nursing care or grade mix or nurs * staff mix * or } \\
\text { nursing grade * or care hours per patient }{ }^{*} \text { ).mp. }\end{array}$ \\
\hline 13 & exp Nursing Staff, Hospital/or Nursing/ \\
\hline 14 & 11 or 12 or 13 \\
\hline 15 & exp Psychiatric Nursing/ \\
\hline 16 & $\begin{array}{l}\text { (mental health registered nurs * or mental health nurs } \\
\text { * or psych * nurs *).mp. }\end{array}$ \\
\hline 17 & 15 or 16 \\
\hline 18 & 9 and 14 and 17 \\
\hline 19 & limit 18 to English language \\
\hline
\end{tabular}

\subsection{Eligibility Criteria}

Our inclusion criteria were:

- Observational and experimental studies.

- Conducted in an acute-inpatient psychiatric unit. 
- The manuscript was written in English.

- Involving patients aged 18 years or over.

- $\quad$ Reported registered mental health-to-registered nurse ratio as the measure of skill mix.

- Readmission to psychiatric inpatient care or referral to a mental health crisis team was a reported outcome.

We did not search for the grey literature because such studies have often not been through a rigorous peer-review process and the search strategies cannot be described in a replicable way.

\section{Results}

Figure 1 shows the flow of papers through the review process. Our initial search identified 7956 citations, of which 1811 were duplicates and were removed. A total of 6141 citations were excluded during the title-and-abstract screening. The full texts of four studies were reviewed [52-55] but rejected because they did not have the right exposure (registered nurse to registered mental health nurse ratio). Two of the studies also had the wrong outcome $[54,55]$.

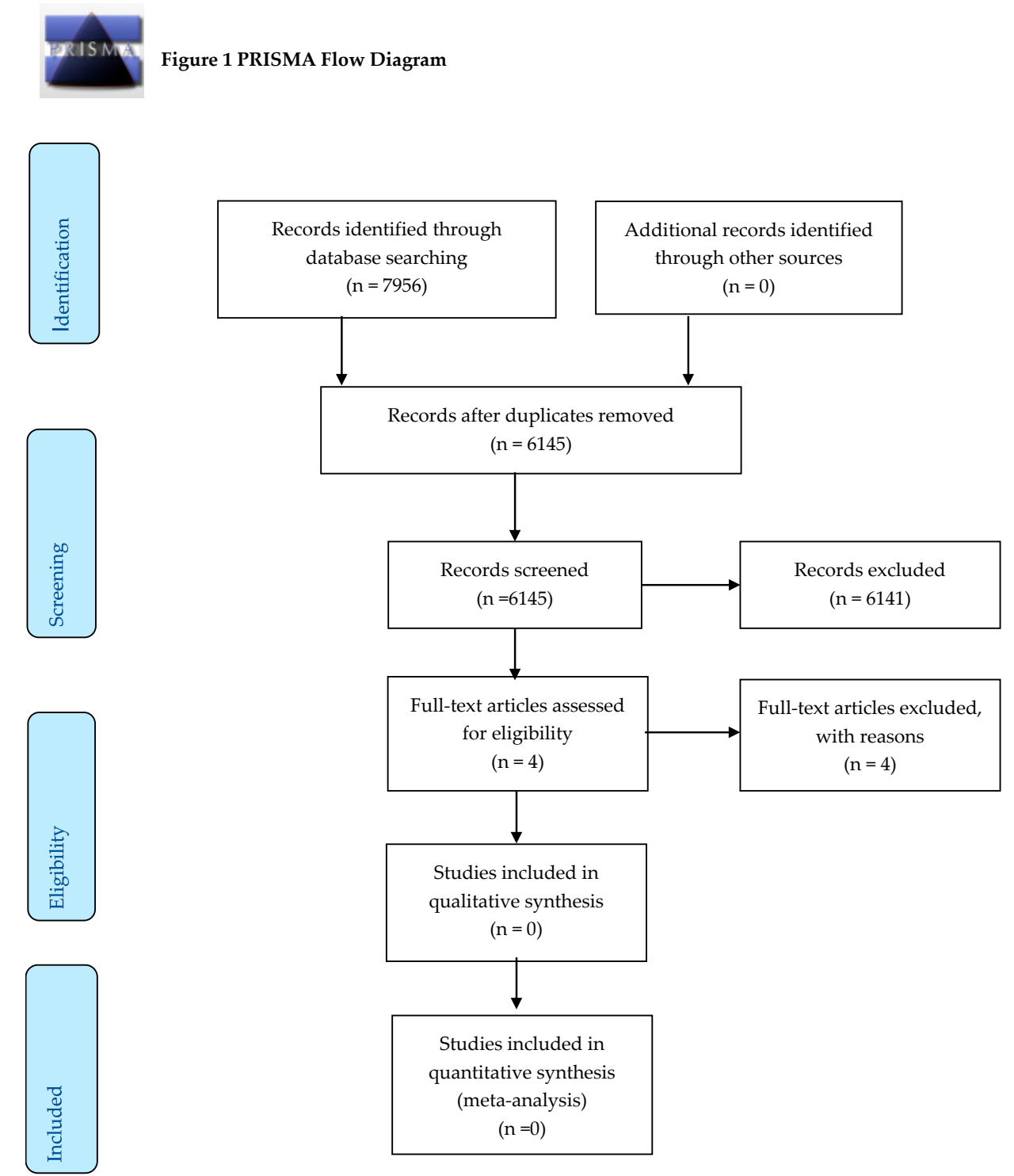

Figure 1. Preferred Reporting Items for Systematic Reviews and Meta-Analyses 2015 (PRISMA) flow diagram. 
Since no studies were included, no detailed data synthesis or assessment of risk of bias in individual studies was performed.

\section{Excluded Studies}

Empty reviews should summarise studies that were excluded at full-text screening, because these studies may provide relevant observations [56]. Table 2 summarises the key findings from the four studies excluded at full-text screening [52-55]. One study was not relevant to the aim of the review [52] - it examined the effect of industrial action by nursing staff on the clinical characteristics of admitted patients. The three other studies were focused on aspects of nursing skill mix and clinical outcomes in a mental health setting [53-55].

Han et al. [53] examined the association between nurse staffing and mental health care readmission within 30 days of discharge in 114 hospitals in South Korea. Data were extracted from the National Health Insurance claim dataset. The authors report an association between readmission rates (within 30 days of discharge) and the number of nurses working in the hospital. The odds of readmission were $5 \%$ lower for every 10 extra nurses per hospital. The [53] study provides some evidence that nurse skill mix may be associated with patient outcomes in inpatient mental health settings. However, the authors report few details about the accuracy and completeness of the data they extracted. For example, it is not clear how many missing data there were and whether there were systematic reasons why these data were missing. Important information about nurse staffing (e.g., age, qualifications, education and years of experience) were seemingly not extracted. These variables are likely confounders; the authors do not provide a commentary about why these key variables were omitted from the analysis. The authors' failure to adequately adjust for confounding in this study severely restricts the value of the reported association.

De Lacy et al. [54] determined the association between nursing skill mix (nurse-to-patient ratio and ratio of registered and non-registered nurses) and rates of seclusion and restraint in six public psychiatric hospitals in the United States. The nurse-to-patient ratio for each participating hospital was calculated daily over the four years of the study. As far as we can determine, the nurse-to-patient ratio was calculated by dividing the number of full-time equivalent (FTE) nurses (registered and unregistered) by the average number of patients in the hospital over the study period. The use of the average number of inpatients as the denominator in this calculation may potentially lead to an over- or under-estimation of the actual nurse-to-patient ratio; this is because the number of inpatients may vary over time. For example, at weekends or during public holidays, there may be a reduction in the number of patients in the hospital. We wanted to check if our interpretation about how skill mix was calculated was correct, but contact details for the author were not reported in the publication (a university thesis). The registered-to-unregistered nurse ratio was calculated, again each day, by dividing the numbers of FTE-registered nurses by the total numbers of nurses working in the participating hospitals [54]. As with the nurse-to-patient ratio, the same caveats apply to how the skill mix was calculated.

Seclusion and restraint were the outcome in the De Lacy et al. [54] study. This was calculated at the hospital level by dividing the number of recorded seclusion events, again, by the average daily census number of patients. Still, the use of the likely average number of hospital patients impacts the precision of the measure. De Lacy et al. [54] do not report a significant association between the two skill-mix measures (the nurse-to-patient and registered-to-unregistered nurse ratios) and the use of seclusion and restraint. The authors state that there was a statistically significant association between both skill-mix measures and the number of episodes of seclusion and restraint. The authors acknowledged that important confounders were not adjusted for in their analysis (e.g., diagnosis, psychoactive medications, the numbers of scheduled individual and group treatments offered). As a consequence, the reported association needs to be interpreted with considerable caution. 
Table 2. Summary of the studies excluded at full-text screening.

\begin{tabular}{|c|c|c|c|c|c|c|c|}
\hline Author & Setting & Design & Exposure & $\begin{array}{l}\text { Measure of } \\
\text { Exposure }\end{array}$ & Outcome & Results & $\begin{array}{l}\text { Reason for } \\
\text { Exclusion }\end{array}$ \\
\hline $\begin{array}{c}\text { Han et al., } 2015 \\
\text { [53] }\end{array}$ & South Korea & $\begin{array}{l}\text { Observational } \\
\text { study }\end{array}$ & $\begin{array}{l}\text { Psychiatrists and } \\
\text { nurse staffing }\end{array}$ & $\begin{array}{c}\text { Number of nurses } \\
\text { Proportion of } \\
\text { experienced } \\
\text { psychiatrists }\end{array}$ & $\begin{array}{c}\text { Readmission } \\
\text { within } 30 \text { days of } \\
\text { discharge }\end{array}$ & $\begin{array}{c}\text { The odds of } \\
\text { readmission were } \\
5 \% \text { lower for every } \\
10 \text { extra nurses per } \\
\text { hospital. }\end{array}$ & Wrong exposure \\
\hline $\begin{array}{c}\text { Abdelkader et al., } \\
1990 \text { [52] }\end{array}$ & England & $\begin{array}{l}\text { Comparison } \\
\text { study }\end{array}$ & $\begin{array}{l}\text { Nurses' industrial } \\
\text { action }\end{array}$ & $\begin{array}{l}\text { Six-month period } \\
\text { during the } \\
\text { industrial action in } \\
1982\end{array}$ & Admission & $\begin{array}{l}\text { In } 1982 \text {, there was } \\
\text { a reduction in the } \\
\text { total number of } \\
\text { admissions by } 30 \% \\
\text { compared to } 1981 .\end{array}$ & Wrong exposure \\
\hline $\begin{array}{c}\text { Bowers et al., } 2012 \\
\text { [55] }\end{array}$ & England & $\begin{array}{c}\text { Time series } \\
\text { analysis }\end{array}$ & $\begin{array}{l}\text { Nursing staff } \\
\text { numbers }\end{array}$ & $\begin{array}{l}\text { Numbers of } \\
\text { nursing staff on } \\
\text { duty }\end{array}$ & $\begin{array}{l}\text { Conflict and } \\
\text { containment } \\
\text { incidents }\end{array}$ & $\begin{array}{c}\text { An increase in } \\
\text { qualified nurses } \\
\text { working on a ward } \\
\text { was associated } \\
\text { with a subsequent } \\
\text { increase in conflict } \\
\text { and containment } \\
\text { incidents. }\end{array}$ & $\begin{array}{l}\text { Wrong exposure } \\
\text { and outcome }\end{array}$ \\
\hline $\begin{array}{c}\text { De Lacy et al., } 2006 \\
{[54]}\end{array}$ & United States & $\begin{array}{l}\text { Descriptive } \\
\text { correlational } \\
\text { research }\end{array}$ & $\begin{array}{c}\text { Nursing staff } \\
\text { numbers and skill } \\
\text { mix }\end{array}$ & $\begin{array}{l}\text { Nursing care } \\
\text { staffing } \\
\text { Nursing staff } \\
\text { numbers } \\
\text { Nursing skill mix } \\
\text { Full-time } \\
\text { equivalents }\end{array}$ & $\begin{array}{l}\text { Seclusion and } \\
\text { restraint use }\end{array}$ & $\begin{array}{l}\text { An increased } \\
\text { proportion of } \\
\text { registered nurses } \\
\text { was associated } \\
\text { with a decrease in } \\
\text { seclusion- and } \\
\text { restraint-use } \\
\text { measures. }\end{array}$ & $\begin{array}{l}\text { Wrong exposure } \\
\text { and outcome }\end{array}$ \\
\hline
\end{tabular}


Bowers et al. [55] conducted an observational study to determine whether an increase in nurse-staffing levels preceded or followed changes in the rates of conflict and containment in inpatient psychiatric wards. The study involved 32 acute wards in England. The authors used the Patient-Staff Conflict Checklist (PCC-SR) to measure rates of conflict and containment. The PCC-SR is an end-of-shift report completed by nurses about the frequency of conflict and containment (e.g., aggression, manual restraint, absconding and forced medication administration) events [56]. There are several potential sources of bias in the study [55] that need to be considered when interpreting the results. In the paper, the authors refer to the validity of PCC-SR, citing a paper by themselves [57]. In this paper, the author reported a statistically significant—but weak—correlation $(r=0.24)$ between the PCC-SR and "officially reported incidents" [57]. Whether the reported correlational data provide evidence that the PCC-SR is valid is a matter of conjecture. As we have already noted, it is generally accepted that "official reports" are likely to underestimate the actual number of incidents, i.e., the PCC-SR is a valid measure of a measure that is generally considered not to be valid [58-60]. In the Bowers et al. [55] study, the authors selected a sub-sample of 32 of the 136 participating wards for this secondary analysis. The selected wards had a high level of compliance with completing the PCC-SR at the end of the shift. It is not stated-though it seems likely-that this analysis was post hoc and not planned a priori. The authors confirm that the included wards were different to the sample as a whole; for example, they had higher bed numbers. Bowers et al. [55] downplay the differences between the two groups by using temperate language (e.g., slightly higher and marginally lower) in the results section of their manuscript. The key observation in the [55] study was that the more nurses working on a shift, the greater the number of incidents. The most likely explanation for the reported association is bias; consequently, we argue, the observations should be treated with some caution.

\section{Discussion}

This systematic review aimed to identify and synthesize evidence for an association between the mental health-to-registered nurse ratio and relapse in inpatient mental health settings. No studies met our inclusion criteria; consequently, we report an empty review. We have identified the need for high-quality skill-mix research to determine optimal and safe staffing in mental-inpatient settings.

An empty review is a systematic review that finds no primary studies eligible for inclusion [61]. Empty reviews are common; for example, in 2010, 9\% of the 4320 reviews published in the Cochrane Library were empty reviews [61]. Paper [62] reported that there is some evidence to suggest that authors do not submit empty reviews because they perceive they will be challenging to get published. Empty reviews make an essential contribution to our understanding of problems because they identify gaps in knowledge that need to be addressed in future research [61].

While there have been many extensive studies that have established an association between nursing skill mix and patient outcomes [28,31,54], few studies have examined the effect of mental health nursing skill mix and patient outcomes. There is not a complete absence of nursing skill-mix research in mental health. For example, we noted two studies that have tested the associations between the nurse-to-patient ratio and patient outcomes-typically, the number of incidents of violence and aggression-in inpatient mental health settings (e.g., [53,55]). Readmission has been used in both general wards and psychiatric wards as an outcome in skill-mix studies. For example, [53] reported that psychiatric hospitals with higher nurse-staffing numbers were associated with lower rates of admission.

\section{Review Limitations}

There are some limitations to our review that are important to consider. It could be argued that we should have undertaken a scoping review of the mental health nursing skill-mix research to inform the viability of a systematic review. A scoping review is a type of review that provides a preliminary assessment of the potential size and scope of the available research literature [63]. It can inform researchers as to whether a full systematic review is needed. Scoping reviews cannot be regarded as 
a final output in their own right, mainly because limitations in their rigour and their duration mean that they hold the potential for bias [63].

In this review, our outcome of interest was admission to acute services. This is an outcome that is extensively used in mental health services research [46,64]. Skill-mix research in medical and surgical settings has tended to use mortality as an outcome $[3,65]$. This would not be appropriate in mental health settings because death is a rare-albeit not unheard of-event. Untoward incidents (e.g., the number of violent incidents) is an alternative measure but is essentially impossible to measure in a valid way. The definition and reporting of untoward incidents vary among hospitals, making it impossible to aggregate them as a meaningful measure. For example, a hospital can report an incident as an untoward incident, but the same may not be reported as an untoward incident by another hospital. The untoward incidents in hospitals are underreported [58-60]. We did identify studies where the number of untoward incidents was the reported outcome. There may be merit in undertaking a systematic review where untoward incidents are the outcome of interest.

In this review, we focused on a single primary outcome. We could have included skill-mix studies with any outcome. However, there is a considerable risk of selective-reporting bias, where the study authors select, post hoc, the most interesting outcomes [66].

Our review was restricted to the English language and did not include grey literature. If there are unpublished studies or studies from other languages regarding our topic, they might have been missed.

\section{Conclusions}

There are no peer-reviewed studies that test the association between the registered mental health-to-registered nurse ratio and psychiatric readmission (or referral to a mental health crisis service) in adult psychiatric inpatients. This is a gap in knowledge that would benefit from further investigation.

Author Contributions: N.M. conceptualised the review, design of the review, data extraction, screening and synthesis, and wrote the initial draft. D.K. and S.P. performed the title-and-abstract and full-text screening. R.G. and M.J. supervised the review and edited the manuscript. L.R. and S.G. independently reviewed the search strategy. All authors have read and agreed to the published version of the manuscript.

Funding: This study was part of a doctoral studentship from La Trobe University.

Conflicts of Interest: The authors declare no conflict of interest.

\section{References}

1. Blegen, M.A.; Vaughn, T.E.; Goode, C.J. Nurse experience and education: Effect on quality of care. J. Nurs. Adm. 2001, 31, 33-39. [CrossRef] [PubMed]

2. Aiken, L.H.; Clarke, S.P.; Cheung, R.B.; Sloane, D.M.; Silber, J.H. Educational levels of hospital nurses and surgical patient mortality. JAMA 2003, 290, 1617-1623. [CrossRef] [PubMed]

3. Sasichay-Akkadechanunt, T.; Scalzi, C.C.; Jawad, A.F. The relationship between nurse staffing and patient outcomes. J. Nurs. Adm. 2003, 33, 478-485. [CrossRef] [PubMed]

4. Estabrooks, C.A.; Midodzi, W.K.; Cummings, G.G.; Ricker, K.L.; Giovannetti, P. The Impact of Hospital Nursing Characteristics on 30-Day Mortality. Nurs. Res. 2005, 54, 74-84. [CrossRef] [PubMed]

5. Kutney-Lee, A.; Aiken, L.H. Effect of nurse staffing and education on the outcomes of surgical patients with comorbid serious mental illness. Psychiatr. Serv. 2008, 59, 1466-1469. [CrossRef] [PubMed]

6. Sales, A.; Sharp, N.; Li, Y.-F.; Lowy, E.; Greiner, G.; Liu, C.-F.; Alt-White, A.; Rick, C.; Sochalski, J.; Mitchell, P.H.; et al. The association between nursing factors and patient mortality in the Veterans Health Administration: The view from the nursing unit level. Med. Care 2008, 46, 938-945. [CrossRef]

7. Van den Heede, K.; Lesaffre, E.; Diya, L.; Vleugels, A.; Clarke, S.P.; Aiken, L.H.; Sermeus, W. The relationship between inpatient cardiac surgery mortality and nurse numbers and educational level: Analysis of administrative data. Int. J. Nurs. Stud. 2009, 46, 796-803. [CrossRef] [PubMed]

8. Lucero, R.J.; Lake, E.T.; Aiken, L.H. Nursing care quality and adverse events in US hospitals. J. Clin. Nurs. 2010, 19, 2185-2195. [CrossRef] 
9. Sermeus, W.; Aiken, L.H.; Van den Heede, K.; Rafferty, A.M.; Griffiths, P.; Moreno-Casbas, M.T.; Busse, R.; Lindqvist, R.; Scott, A.P.; Bruyneel, L.; et al. Nurse forecasting in Europe (RN4CAST): Rationale, design and methodology. BMC Nurs. 2011, 10, 6. [CrossRef]

10. Aiken, L.H.; Cimiotti, J.P.; Sloane, D.M.; Smith, H.L.; Flynn, L.; Neff, D.F. Effects of nurse staffing and nurse education on patient deaths in hospitals with different nurse work environments. J. Nurs. Adm. 2012, 42 (Suppl. 10), S10-S16. [CrossRef]

11. Blegen, M.A.; Goode, C.J.; Park, S.H.; Vaughn, T.; Spetz, J. Baccalaureate education in nursing and patient outcomes. J. Nurs. Adm. 2013, 43, 89-94. [CrossRef] [PubMed]

12. Kutney-Lee, A.; Sloane, D.M.; Aiken, L.H. An increase in the number of nurses with baccalaureate degrees is linked to lower rates of postsurgery mortality. Health Aff. 2013, 32, 579-586. [CrossRef] [PubMed]

13. McHugh, M.D.; Kelly, L.A.; Smith, H.L.; Wu, E.S.; Vanak, J.M.; Aiken, L.H. Lower mortality in magnet hospitals. Med. Care 2013, 51, 382-388. [CrossRef] [PubMed]

14. Kelly, D.M.; Kutney-Lee, A.; McHugh, M.D.; Sloane, D.M.; Aiken, L.H. Impact of Critical Care Nursing on 30-Day Mortality of Mechanically Ventilated Older Adults. Crit. Care Med. 2014, 42, 1089-1095. [CrossRef] [PubMed]

15. Yakusheva, O.; Lindrooth, R.; Weiss, M. Economic evaluation of the $80 \%$ baccalaureate nurse workforce recommendation: A patient-level analysis. Med. Care 2014, 52, 864-869. [CrossRef] [PubMed]

16. Aiken, L.H.; Sloane, D.M.; Bruyneel, L.; Van den Heede, K.; Griffiths, P.; Busse, R.; Diomidous, M.; Kinnunen, J.; Kózka, M.; Lesaffre, E.; et al. Nurse staffing and education and hospital mortality in nine European countries: A retrospective observational study. Lancet 2014, 383, 1824-1830. [CrossRef]

17. Ma, C.; McHugh, M.D.; Aiken, L.H. Organization of Hospital Nursing and 30-Day Readmissions in Medicare Patients Undergoing Surgery. Med. Care 2015, 53, 65-70. [CrossRef]

18. Cho, E.; Sloane, D.M.; Kim, E.-Y.; Kim, S.; Choi, M.; Yoo, I.Y.; Lee, H.S.; Aiken, L.H. Effects of nurse staffing, work environments, and education on patient mortality: An observational study. Int. J. Nurs. Stud. 2015, 52, 535-542. [CrossRef]

19. Gkantaras, I.; Mahfoud, Z.R.; Foreman, B.; Thompson, D.R.; Cannaby, A.-M.; Deshpande, D.H.; Watson, R.; Topping, A.; Gray, R. The effect of Nurse GraduaTeness on patient mortality: A cross sectional survey (the NuGaT study). J. Adv. Nurs. 2016, 72, 3034-3044. [CrossRef]

20. Aiken, L.H.; Sloane, D.; Griffiths, P.; Rafferty, A.M.; Bruyneel, L.; McHugh, M.; Maier, C.B.; Moreno-Casbas, M.T.; Ball, J.E.; Ausserhofer, D.; et al. Nursing skill mix in European hospitals: Cross-sectional study of the association with mortality, patient ratings, and quality of care. BMJ Qual. Saf. 2016, 26, 559-568. [CrossRef]

21. Ball, J.E.; Bruyneel, L.; Aiken, L.H.; Sermeus, W.; Sloane, D.M.; Rafferty, A.M.; Lindqvist, R.; Tishelman, C.; Griffiths, P. RN4Cast Consortium Post-operative mortality, missed care and nurse staffing in nine countries: A cross-sectional study. Int. J. Nurs. Stud. 2018, 78, 10-15. [CrossRef] [PubMed]

22. Scott, W.R.; Forrest, W.H., Jr.; Brown, B.W., Jr. Hospital structure and postoperative mortality and morbidity. In Organizational Research in Hospitals; Shortell, S.M., Brown, M., Eds.; Blue Cross Association: Chicago, IL, USA, 1976; pp. 72-89.

23. Hall, L.M.; Doran, D.; Pink, G.H. Nurse staffing models, nursing hours, and patient safety outcomes. J. Nurs. Adm. 2004, 34, 41-45. [CrossRef] [PubMed]

24. Crowe, M.; Carlyle, D. Deconstructing risk assessment and management in mental health nursing. J. Adv. Nurs. 2003, 43, 19-27. [CrossRef]

25. Pangman, V.C.; Sloan, J.; Guse, L. An examination of psychometric properties of the Mini-Mental State Examination and the Standardized Mini-Mental State Examination: Implications for clinical practice. Appl. Nurs. Res. ANR 2000, 13, 209-213. [CrossRef] [PubMed]

26. Uppendahl, J.R.; Alozkan-Sever, C.; Cuijpers, P.; de Vries, R.; Sijbrandij, M. Psychological and Psychosocial Interventions for PTSD, Depression and Anxiety Among Children and Adolescents in Low- and Middle-Income Countries: A Meta-Analysis. Front. Psychiatry 2020, 10, 933. [CrossRef]

27. Leach, M.J.; Jones, M.; Bressington, D.; Jones, A.; Nolan, F.; Muyambi, K.; Gillam, M.; Gray, R. The association between community mental health nursing and hospital admissions for people with serious mental illness: A systematic review. Syst. Rev. 2020, 9,1-8. [CrossRef]

28. Staggs, V.S. Nurse staffing, RN mix, and assault rates on psychiatric units. Res. Nurs. Health 2012, 36, 26-37. [CrossRef] 
29. Bowers, L.; Allan, T.; Simpson, A.; Nijman, H.; Warren, J. Adverse incidents, patient flow and nursing workforce variables on acute psychiatric wards: The Tompkins Acute Ward Study. Int. J. Soc. Psychiatry 2007, 53, 75-84. [CrossRef]

30. Melvin, M.; Hall, P.; Bienek, E. Redesigning acute mental health services: An audit into the quality of inpatient care before and after service redesign in Grampian. J. Psychiatr. Ment. Health Nurs. 2005, 12, 733-738. [CrossRef]

31. Chou, K.R.; Lu, R.B.; Mao, W.C. Factors relevant to patient assaultive behavior and assault in acute inpatient psychiatric units in Taiwan. Arch. Psychiatr. Nurs. 2002, 16, 187-195. [CrossRef]

32. Jansen, G.; Dassen, T.; Moorer, P. The Perception of Aggression. Scand. J. Caring Sci. 1997, 11, 51-55. [CrossRef] [PubMed]

33. Morris, D.W.; Ghose, S.; Williams, E.; Brown, K.; Khan, F. Evaluating psychiatric readmissions in the emergency department of a large public hospital. Neuropsychiatr. Dis. Treat. 2018, 14, 671-679. [CrossRef] [PubMed]

34. Howes, O.D.; Vergunst, F.; Gee, S.; McGuire, P.; Kapur, S.; Taylor, D. Adherence to treatment guidelines in clinical practice: Study of antipsychotic treatment prior to clozapine initiation. Br. J. Psychiatry 2012, 201, 481-485. [CrossRef] [PubMed]

35. Nielsen, J.; Dahm, M.; Lublin, H.; Taylor, D.M. Psychiatrists' attitude towards and knowledge of clozapine treatment. J. Psychopharmacol. 2009, 24, 965-971. [CrossRef] [PubMed]

36. Kelly, G.R.; Scott, J.E. Medication compliance and health education among outpatients with chronic mental disorders. Med. Care 1990, 28, 1181-1197. [CrossRef] [PubMed]

37. Bowie, C.R.; Depp, C.A.; McGrath, J.; Wolyniec, P.; Mausbach, B.T.; Thornquist, M.H.; Luke, J.; Patterson, T.L.; Harvey, P.D.; Pulver, A.E. Prediction of real-world functional disability in chronic mental disorders: A comparison of schizophrenia and bipolar disorder. Am. J. Psychiatry 2010, 167, 1116-1124. [CrossRef]

38. Schennach, R.; Obermeier, M.; Meyer, S.; Jäger, M.; Schmauss, M.; Laux, G.; Pfeiffer, H.; Naber, D.; Schmidt, L.G.; Gaebel, W.; et al. Predictors of relapse in the year after hospital discharge among patients with schizophrenia. Psychiatr. Serv. 2012, 63, 87-90. [CrossRef]

39. Rieke, K.; McGeary, C.; Schmid, K.K.; Watanabe-Galloway, S. Risk Factors for Inpatient Psychiatric Readmission: Are There Gender Differences? Community Ment. Health J. 2015, 52, 675-682. [CrossRef]

40. Lopez, N.; Sethi, F. The 'revolving door': A study of factors involved in readmissions to a women's psychiatric intensive care unit. J. Psychiatr. Intensive Care 2017, 13, 3-9. [CrossRef]

41. Rumball-Smith, J.; Hider, P. The validity of readmission rate as a marker of the quality of hospital care, and a recommendation for its definition. N. Z. Med. J. 2009, 122, 63-70.

42. Barnett, R.; Lauer, G. Urban deprivation and public hospital admissions in Christchurch, New Zealand, 1990-1997. Health Soc. Care Community 2003, 11, 299-313. [CrossRef] [PubMed]

43. Kilkenny, M.; Dewey, H.M.; Sundararajan, V.; Andrew, N.E.; Lannin, N.A.; Anderson, C.; Donnan, G.; Cadilhac, D.A. Readmissions after stroke: Linked data from the Australian Stroke Clinical Registry and hospital databases. Med. J. Aust. 2015, 203, 102-106. [CrossRef] [PubMed]

44. Askren-Gonzalez, A.; Frater, J. Case management programs for hospital readmission prevention. Prof. Case Manag. 2012, 17, 219-226. [CrossRef] [PubMed]

45. Gerson, L.D.; Rose, L.E. Needs of persons with serious mental illness following discharge from inpatient treatment: Patient and family views. Arch. Psychiatr. Nurs. 2012, 26, 261-271. [CrossRef] [PubMed]

46. Ascher-Svanum, H.; Zhu, B.; Faries, D.E.; Salkever, D.; Slade, E.P.; Peng, X.; Conley, R.R. The cost of relapse and the predictors of relapse in the treatment of schizophrenia. BMC Psychiatry 2010, 10, 2. [CrossRef]

47. World Health Organization. WHO Europe Occupational Health Nursing Curriculum, WHO European Strategy for Continuing Education for Nurses and Midwives 2003; WHO: Copenhagen, Denmark, 2003.

48. Blythe, J.; White, J. Role of the mental health nurse towards physical health care in serious mental illness: An integrative review of 10 years of UK Literature. Int. J. Ment. Health Nurs. 2012, 21, 193-201. [CrossRef]

49. Gray, R.; Brown, E. What does mental health nursing contribute to improving the physical health of service users with severe mental illness? A thematic analysis. Int. J. Ment. Health Nurs. 2016, 26, 32-40. [CrossRef]

50. Moyo, N.; Jones, M.; Gilbert, S.; Romero, L.; Gray, R. The association between mental health nurse to registered nurse ratio and patient outcomes in psychiatric inpatient wards: Protocol for a systematic review. J. Psychiatr. Ment. Health Nurs. 2020. [CrossRef] 
51. Moher, D.; Shamseer, L.; Clarke, M.; Ghersi, D.; Liberati, A.; Petticrew, M.; Shekelle, P.; Stewart, L.A. Preferred reporting items for systematic review and meta-analysis protocols (PRISMA-P) 2015 statement. Syst. Rev. 2015, 4, 1. [CrossRef]

52. Abdelkader, M.; Macmillan, J.F. The effect of a nurses' industrial action on psychiatric hospital admissions. Soc. Psychiatry Psychiatr. Epidemiol. 1990, 25, 154-158. [CrossRef]

53. Han, K.T.; Kim, S.J.; Jang, S.I.; Hahm, M.-I.; Kim, S.J.; Lee, S.Y.; Park, E.C. The outcomes of psychiatric inpatients by proportion of experienced psychiatrists and nurse staffing in hospital: New findings on improving the quality of mental health care in South Korea. Psychiatry Res. 2015, 229, 880-886. [CrossRef] [PubMed]

54. De Lacy, L.; Maddox, P.J. The Influence of Nursing Staff Numbers and Skill Mix on Seclusion and Restraint Use in Public Psychiatric Hospitals. Ph.D. Thesis, George Mason University, Fairfax, VA, USA, 2006.

55. Bowers, L.; Crowder, M. Nursing staff numbers and their relationship to conflict and containment rates on psychiatric wards-A cross sectional time series poisson regression study. Int. J. Nurs. Stud. 2012, 49, 15-20. [CrossRef] [PubMed]

56. Bowers, L.; Douzenis, A.; Galeazzi, G.M.; Forghieri, M.; Tsopelas, C.; Simpson, A.; Allan, T. Disruptive and dangerous behaviour by patients on acute psychiatric wards in three European centres. Soc. Psychiatry Psychiatr. Epidemiol. 2005, 40, 822-828. [CrossRef] [PubMed]

57. Bowers, L.; Brennan, G.; Flood, C.; Lipang, M.; Oladapo, P. Preliminary outcomes of a trial to reduce conflict and containment on acute psychiatric wards: City Nurses. J. Psychiatr. Ment. Health Nurs. 2006, 13, 165-172. [CrossRef]

58. Lion, J.R.; Synder, W.; Merrill, G.L. Underreporting of assaults on staff in a state hospital. Hosp. Community Psychiatry 1981, 32, 497-498. [CrossRef]

59. Owen, C.; Tarantello, C.; Jones, M.P.; Tennant, C. Violence and Aggression in Psychiatric Units. Psychiatr. Serv. 1998, 49, 1452-1457. [CrossRef]

60. Hogarth, K.M.; Beattie, J.; Morphet, J. Nurses' attitudes towards the reporting of violence in the emergency department. Australas. Emerg. Nurs. J. 2016, 19, 75-81. [CrossRef]

61. Yaffe, J.; Montgomery, P.; Hopewell, S.; Shepard, L.D. Empty Reviews: A Description and Consideration of Cochrane Systematic Reviews with No Included Studies. PLoS ONE 2012, 7, e36626. [CrossRef]

62. Lang, A.; Edwards, N.; Fleiszer, A. Empty systematic reviews: Hidden perils and lessons learned. J. Clin. Epidemiol. 2007, 60, 595-597. [CrossRef]

63. Grant, M.J.; Booth, A. A typology of reviews: An analysis of 14 review types and associated methodologies. Health Inf. Libr. J. 2009, 26, 91-108. [CrossRef]

64. Malik, N.; Kingdon, D.; Pelton, J.; Mehta, R.; Turkington, D. Effectiveness of brief cognitive-behavioral therapy for schizophrenia delivered by mental health nurses: Relapse and recovery at 24 months. J. Clin. Psychiatry 2009, 70, 201-207. [CrossRef] [PubMed]

65. Wiltse Nicely, K.L.; Sloane, U.M.; Aiken, L.H. Lower mortality for abdominal aortic aneurysm repair in high-volume hospitals is contingent upon nurse staffing. Health Serv. Res. 2012, 48, 972-991. [CrossRef] [PubMed]

66. McKenzie, J.E.; Brennan, S.E.; Ryan, R.E.; Thomson, H.J.; Johnston, R.V.; Thomas, J. Chapter 3: Defining the criteria for including studies and how they will be grouped for the synthesis. In Cochrane Handbook for Systematic Reviews of Interventions Version 6.0; Higgins, J.P.T., Thomas, J., Chandler, J., Cumpston, M., Li, T., Page, M.J., Welch, V.A., Eds.; updated July 2019; John Wiley \& Sons: Chichester, UK, 2019; Available online: www.training.cochrane.org/handbook (accessed on 12 April 2020).

(C) 2020 by the authors. Licensee MDPI, Basel, Switzerland. This article is an open access article distributed under the terms and conditions of the Creative Commons Attribution (CC BY) license (http://creativecommons.org/licenses/by/4.0/). 